Acta Orientalia Academiae Scientiarum Hung. Volume 53 (1-2), 47-63 (2000)

\title{
MATERIALS OF THE TUVINIAN LANGUAGE IN CHINA
}

\author{
GENG SHIMIN* \\ (Beijing)
} The author collected linguistic materials among the Tuvinians living in China. The language of the
Tuva in China is basically the same as that spoken in Russia and shows only small local differ-
ences. The texts are given in transcription with translation and commentaries. A list of suffixes and
a glossary are added.

Key words: Turkic languages, Tuva, minorities in China, folklore texts, lexica.

The Tuvinians of China inhabit the high mountain ridges of the Altai Prefecture, Xinjiang Uighur Autonomous Region, along the Chinese-Russian (now Kazakhstan) borders. They live mainly in Xom, Xanas (Buwiršïn County) and Aq Qaba (Qaba County). In addition, a few Tuvinians also live at Temeki (about $6-7 \mathrm{~km}$ to the Northwest of Köktoghay County) and at Köksuw of Altai County as well. They have a population of about 2000. Because the Tuvinians wear Mongolian-style robes and believe in Lamaism, in the official census they are included among the Mongolians by the local government. The local Kazakhs call them Munčaq (or Kök Munčaq), and the Mongols call them Urianghai. They call themselves as Dïba (jurt) or Munčaq. The Tuvinians of China are divided into 7 clans: Qara Soyan, Qïzil Soyan, Orasaq, Aq Soyan and Munčaq, etc. The Tuvinians are engaged mainly in animal husbandry and hunting (mostly in winter).

The following materials of the Tuvinian language were collected by myself 43 years ago, in October, 1956. In August of 1956 when I met in Urumchi the Mongolist of former S.U. Prof. B. H. Todayeva, who just came back from Tarbaqatai (for investigation of Western Mongolian language), she told me that in the Altai Prefecture there exists a part of Mongolians speaking a special "unknown" language. She asked me to clear this question during my investigation of Kazakh dialects there.

After finishing the investigation work of Kazakh dialects, I arrived at Buwïršin County at the end of September. We stayed at a place called Chongqur to the North of the centre of the county for making preparation to enter the remote mountain re-

${ }^{*}$ Geng Shimin, Department of Uighur Language and Culture, Central University for Nationalities, 27 Baishing Road, 100081 Beijing, China

0001-6446/2000/ \$5.00 (C) 2000 Akadémiai Kiadó, Budapest 
gion (to find a guide as well as to buy enough flour and other daily necessities, especially to borrow a gun from the district government for defence against attacks of brown bears). I spent more than a month time investigating the Tuvinian language at 3 places (from East to West, they are Xom, Xanas, Aq Qaba). In the very first week of the investigation, I believed that the investigated language was a special old Turkic

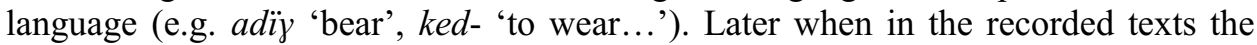
word "diba" or "dïwa jurt" appeared, I realised that it should be corresponding to the "Tuva" of Russia. After I returned to Beijing I compared my materials with the "Tuvinsko-Russkiy Slovar"” (Moscow, 1955) (especially the appendix: Outline of Tuvinian Grammar by $\breve{S}$. Ch. Sat (the only Tuvinian dictionary I could find in Beijing at that time), it was proved that the so-called "unknown" language is basically the same language as spoken in Russia. Then I published an information paper "On the Newly Discovered Tuvinian Language" in the "Newsletter of Minority Languages Investigation" (No. 6, 1957).

At the first night of arriving at Xanas (the first Tuvinian place I visited) when I slept in the open at the bank of Xanas river, a heavy snow fell. Later, as the road returning to Buwïršin was blocked by heavy snow, I was compelled to go westward to Aq Qaba and then through the centre of Qaba County I returned to Buwïršin County at the end of October.

Generally speaking, the Tuvinian language of China (TC) is the same language as the Tuvinian of Russia (TR). There are only some dialectic differences between them. The characteristics of TC can be summarised as follows:

1) Many words with front vowels are pronounced with $k$-instead of $\chi$ - in TR, e.g. köl 'lake', kün, 'day', etc. instead of $\chi \ddot{o l} l, \chi \ddot{u ̈ n}$.

2) In word initial position, $j$ - is instead of č in TR, e.g. ji- 'to eat', jït- 'to lie' instead of či-, čit-.

3) The 2nd per. poss. suffixes are -yar/-ger instead of TR's -yar/-yer, e.g. ұoyuyar 'your sheep', jaylaayar 'your summer pasture' instead of zoyuyar, jaylaayar.

4) Like the Tuvinian in TR, in TC also exist second-grade long vowels coming from contraction - the loss of consonants $g, \gamma, l, r$, e.g. deen 'named' < degen, jiin 'eaten' < jigen, beer 'to be giving' < berer.

5) In the sentences the words beginning with $k$-, $q$ - are always voiced to $g-, \gamma^{-}$, e.g. kel- 'to go', kör- 'to see' become gel-, gör-.

6) As in TR there exists also the pharyngealisation of vowels, e.g. a 't 'horse', $o$ 't 'grass', $e$ 't 'meat', etc. pairing with the unpharyngealised words at 'name', ot 'fire', et 'goods'.

At last, but not least I must mention that during my work in the Tuvinian region I spoke Kazakh to communicate with my informants. Maybe I understood or the informants translated some words or sentences not very precisely. The majority of Tuvinian people in China know Kazakh language. A part of Tuvinian people living at Qanas can also speak Western Mongolian. 
Texts

\section{D. uyannïy uruy}

(1) burun bir šayda bir joqtuy ašqïyaq jorïptïr. (2) oon bir jaštïy jorïptur. (3) onï bir

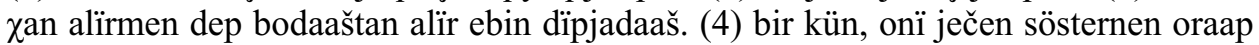
alïrya sayï̌s bitken. (5) bir kün, ol ašqïjaqtï qï(y)yïtïbaap ( qïyyïrtïp alyaš) ïnya aytqan: "sen ööydägi uruunnan mengä külden aryamjï eštirip ber! kerbä aryamjï eštir

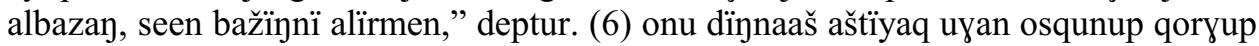

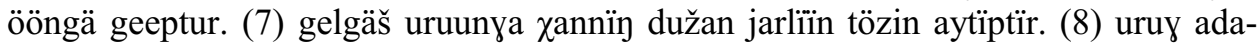
zïnya aytïptur: "sen qortpa, ol belen jibegä," deptur. (9) oon soonda adazïnya bir qu-

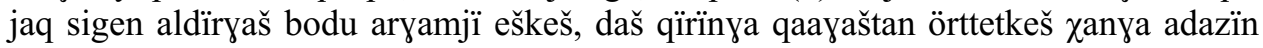
dayïn salïptur. (10) barïp ayt: “ežerin ežïp qaydïm. geep bodu jiïp alsïn,” deptur. (11)

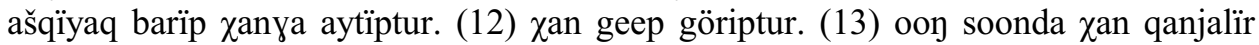
ebin dïppayïn dayïn bir gejää keräk dužaaptur. (14) "ašqïyaq, sen mengä day jerdägi adïnnï̄ ižäänin tözin [mengä] sanap ber.” (15) oon soonda uruy dalašpayïn oluryaš adazïnya aytïptur. (16) "sen barïp iyi ölgen gijinin bažïn ekkel," deptur. (17) ol uruy

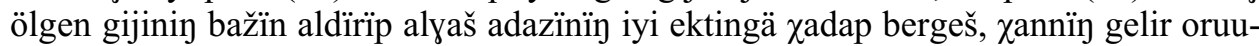

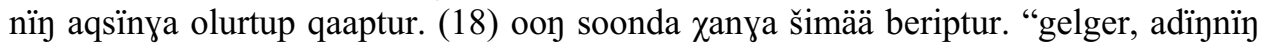

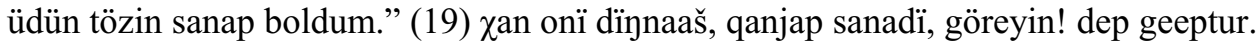

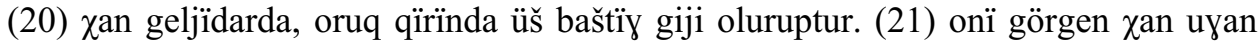
sayǐžïnan adïrlïp ašqïyaqtïn ööngä dezip gelgešten uruyya aytïptur: "men bögün üš baštïy gjiji gördim," deptur. (22) oon soonda uruy aytïptur: "orčalanda ïndïy jibä dolu

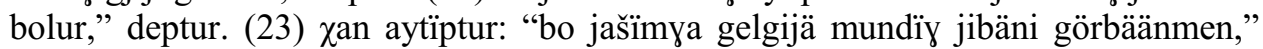
deptur. (24) "siler monï görbään bolsay, adïynïy jejä üdü barïn qanjap bilersen." (25)

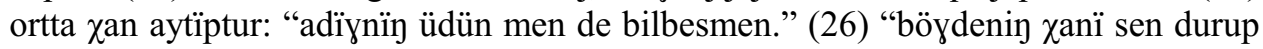
onï bilbään (bolsa), soonda ot qïdiïnda oluryan men qanjap bilirmen." (27) oon soon-

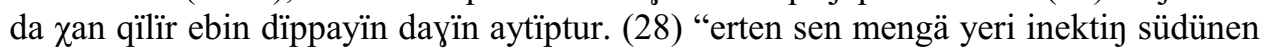

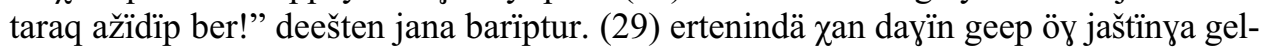
gešten uruynï qïy deptur. (30) uruy: "adïr, adïr," dep bičii doqtaptur. (31) ooy soonda

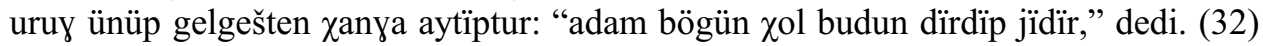

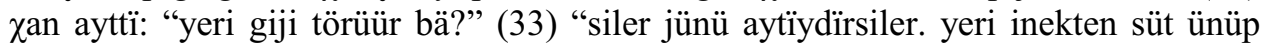

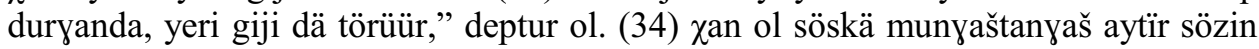

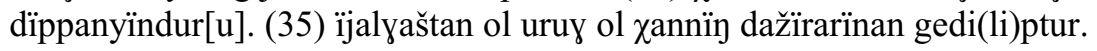

\section{Clever daughter}

\section{Translation}

(1) Once upon a time, there was an old man. (2) He had a young daughter. (3) A khan wanted to marry her, but he could not find a way to take her. (4) One day an idea came to him: through cunning words to get her. (5) One day he sent someone for the old man and said to him: "let your daughter in house twist a rope from ashes for me! If you can't let her make this, I will take away your head." (6) After hearing this, the 
old man lost his wisdom and being very afraid returned home. (7) After he returned home, he told all the khan's delivered order to his daughter. (8) The daughter said to her father: "Don't be afraid, it is an easy matter." (9) Then she let her father bring her an armful of hay. She made a rope and put the rope on a stone and burned it. (10) Then she sent her father to the khan. "You go to tell the khan his rope was ready, and ask him to come to take it himself." (11) The old man went to inform the khan. (12) The khan came and saw (what happened). (13) Finally the khan could not find any measure (to reach his aim). He once again delivered a difficult thing (to the old man). (14) He said to him: "old man, you count for me all the holes of bears at this mountain region." (15) Then, the daughter having no hurry said to her father: (16) "You go to bring me two dead men's heads." (17) The daughter took those dead men's heads and put (lit. stuck) them on her father's shoulder and let him sit at the crossing of a road which the khan takes. (18) Then she gave information to the khan: "please come to have a look, I already counted all the holes of bears." (19) Hearing this news the khan thought: "Let me see how they counted (the holes)." (20) When the khan was coming, he saw a man with three heads sitting at the side of road. (21) The khan feared so much, losing all his wisdom escaped to the old man's house. He said to the daughter: "Today I saw a man with three heads." (22) Then the daughter said: "In this world there are a lot of such things." (23) The khan said: "Up to this age I never saw this kind of thing." (24) (The daughter said:) "If you didn't see this thing, how can I know the number of bears' holes?" (25) Later the khan said: "I also don't know the number of bears' holes." (26) "As a khan of all the people, if you cannot know (the bears' holes), how can I - sitting at the side of fire - know this?" (27) Then, with no measure found, the khan again said: (28) "Tomorrow you bring me yoghurt soured form a bull's milk!" Saying so he returned (to his home). (29) Next day the khan came to the daughter's house and shout at her. (30) The daughter said: "Just wait a minute, just wait a minute." (31) After a little while the daughter went out and said to the khan: "My father today will give birth to a child (lit. 'is pulling his hand and leg')." (32) Then the khan said: "How can a male human being give birth to a child?" (33) The daughter said then: "What are you saying? If a bull can give milk, the male human being can also give birth to a child." (34) Being put in awkward situation by the words of the daughter, the khan could say nothing. (35) So, the daughter was freed from the khan's humiliation.

\section{E. börü men qayay}

(1) ertä burun šayda bir qïriīn qïryan qayay booptur. (2) oon üš bičii jaš oylu bar ergin. (3) bir oylun šay dep adaan, iyinči oylun jïlïy dep adaan, üžünči oylun mïjïy dep adaar ergin. (4) bo qayay yãštïn doorsïnda bir bičii gükpäkkä duryan ergin. (5) ol

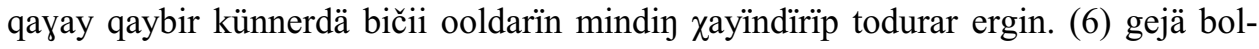
yanda ooldarïn sabïnya oraap jïtqïrar ergin. (7) anjalyaštan, ol qïryan qayay bičii ooldarïnen qadï jobalanjoq äme dzuwup jörüy beer ergin. (8) bir kün qïryan qayay min-

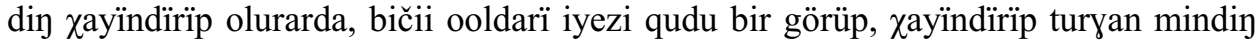




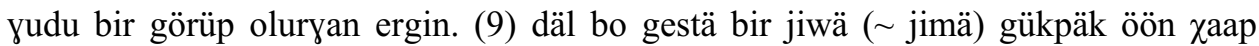
turyanïn dïnnaydïr. (10) “bo yïm?” dep qayay suraaštan ( surabïtqaš) bodu jügürüp ejikkä baryaš dïdïqtan baqïlaydïr. (11) unuun, baqïlaarda bir änäy göstür, oọ soonda dekpiläp alyan ejiin ažïdïwïtqaš, "sen qïmsen? meen joqtuy kükpämgä seni qandïy

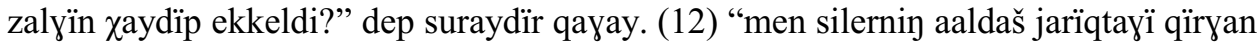
üškünin anayïmen. meen iyem silergä dustaan balïqtï belekkä berip jorttu.” (13) qa-

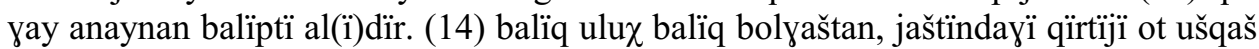
qïlayyaynïp durar ergin. (15) ol balïqtïn semizingä üzü xaaptur ergin. (16) qayay öörip öörügeningä qortïldap iiittaydïr. (17) ol qayay bir eleennen beeri balïq e'din

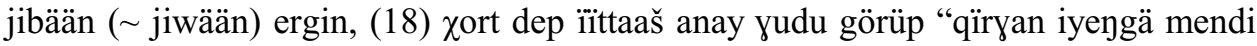
dep ayt," dedi. (19) “yeki!" dep öčük berdi dä, bir mäläbitkäš ( mäläwitkäš) mendiläškäš anay ööngä jana wardï ( bardi). (20) unuun, qayay ojuunya gelgeš jaš ooldarïn iziy mindinmen jemnendirip bodu balïqtï jiirgä olïradir. (21) balïqtï bažinan quduruunya jedir töözin jiidir, büdün sööktäyaanya jedir töözin jiidir. (22) "qay bir kündä munday balïq jip durdum ezä, bayay bolbas iyik," dep bodaydïr qayay. (23) unuun bičii ooldarïn jaštïya edertip üngeš, jïlïy balyašqa jïtqïryaš, bodu qïryan söögin küngä dögäp jïdadïr. (24) unuun, üremäš boljayjoq, qayay bodunïy ooldarïmen qadï jïtqaš, en adaanda, suy ijer durazï geldir. (25) unuun, duryaštan ooldarïnya aytïydür: "senner balyažïyarya jïda durïyar, men suuya ( suyya) barïp geleyin," dedir. (26) anjalyaštan suuya jayyïs oruqtan joy bardï. (27) anjalyaštan, suuya baryaš serin sunnï jilmilenip iže baštadï. (28) suy ižip jïdarda, kenerten qayniïn gelgeni bilinbey bir börü ünüp gel-

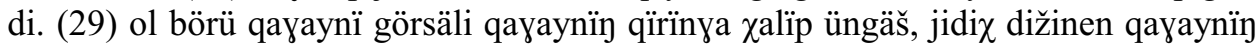

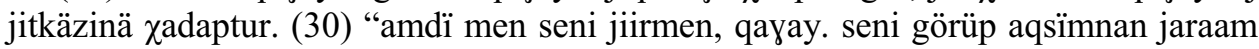

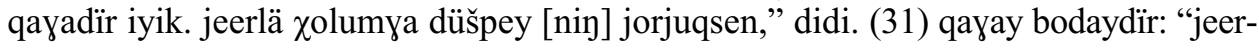
laa gejää boldu!" dep bodaaš "börü qandïy gejää bolsa da, arï ištindä jorsa da, unun aamay an joq. monï aldap göreyin," dep bodaydïr. (32) unuun, qayay aytti: "meni ji-

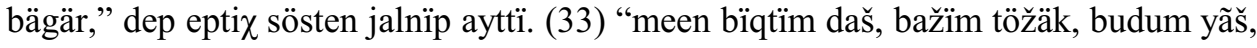

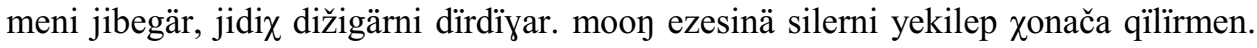
silergä bodumnïy üš oylumnï beermen. meen ooldarïm qïryan emäs, šin dorzuq ušqaš semis, baza baqšadayï alma ušqaš qïp-qïzïl," didi. (34) börü: "seen aytïrïn jigä, bïqtïn daš, bažïn töžäk, damanïn yaš, jidið dižimni seen qïryan söögüngä badiryïja jïmjaq semis ooldarïnnï̈ amdannïy e'din jidim ezä, mengä yeki bolur," didi. (35) qayay gök

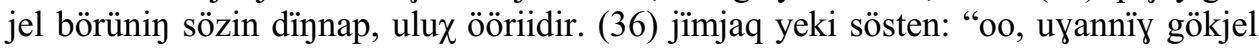
börü, bögün qarayyï düžermen ( bilen) bistin duryan jarïqqa gelgär. unuun, murunay uluy oylumnï, däriy orta ooldï, en sonnan, bičii oylumnï qïyïrdïy ezä, ooldarïm ünüp gelir. ïnjan, jidiger ezä bolur," didi. (37) ol sösti dïnnaan soonda börünin qaraa qïlayłaynïp, dižin janïp: "seen ooldarïnnïn attarï qïm?" dep suraydïr qayaynan. (38) unuun, qayay aytti: "uluunïy adï šay, ortaazïnïy adï jiliix, kenjäzinin adï bǐžì," didi. (39) "yeki, men seni ööngä jorturmen. jayyïs gejä bolurnan seen ooldarïnya baar-

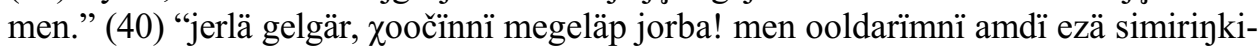
räp durar užun jemnendirip durayïn," dep aytqaš qayay ööngä jügürä bardï. (41) "baarmen, jügä barbasmen!” dep aytqaš börü qïlïn arï qudu girä bardï. (42) arï qudu baar jïtqaš, börü ištindä bodaydïr: "oy, bo qïryan qayaynïn tenee[n] jüdeen tenek! bar ooldarïn mengä berdi. onumen qaybayïn ( qaywayïn) meni gelbes dep qoryadïr," didi. 
(43) qayay ööngä jügürüp gelgeš, bičii ooldarïn balyaštan duryuzup alyaš, süt ištirigeš, ööngä giirgeš, ooldarïn sawïn döžäängä jïtqïryaš, ejiin bǐžï dekpiläš, bodu ooldarïnïn qïdiïnya jïda waldï (aldi). (44) börü gejä oray bolurbilen qïlïn arïxnan üngeš jügürüp gelgeš: (45) "ay, qïryan qayay! šay oylunya ayt, mengä gelsin, soyurdegä boop oynaqay!" dep qïyïrdï. (46) qayay ööngä jïtqaš: "oo, gök börü, öyi ödä bardï

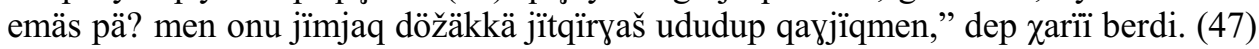
börü ažïnïp ayttii: "ay, qïryan qayay, jilïy oylunya ayt-aan, mennen jaštïp oynaarya jarïqqa gelsin!” dep dayïn qïyïrdï. (48) "meen jïlï oylum bolyaš bašqa ooldar da sabïn

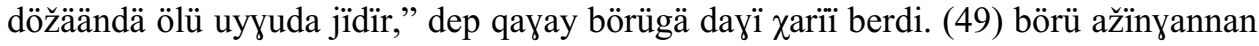

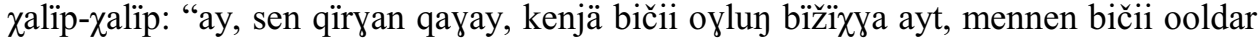
qïlip oynaarya gelsin," dep jarïqtï janyïryalandir dïnsï $\chi$ qišqïrdï. (50) "meen öömnin

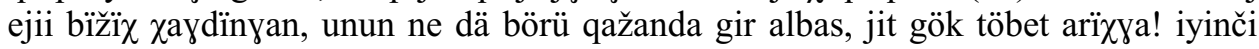

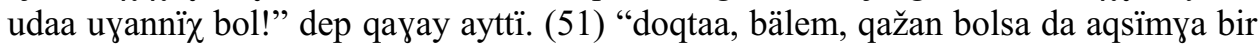

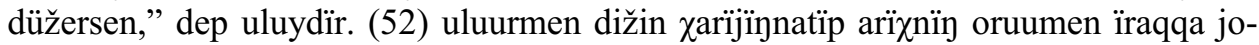
ruy bardï.

\section{E. Wolf and Sow}

\section{Translation}

(1) Early in the past time there was a very old sow. (2) She had three little sons. (3) One son was named Šay (Time), the second one was Jiliy (Warm), the third one was Mijiy (Sturdy). (4) This sow lived in a small hut by the corner of woods. (5) That sow always boiled porridge and fed her sons. (6) In the evening she let them lie down on dried hay. (7) So, that old sow lived together with her little sons with no worry. (8) One day while the old sow was boiling porridge, her little sons were now looking at their mother, now looking at the boiling porridge. (9) Just at that moment, she heard someone was closing their small hut. (10) "Who is this?" asked the sow. Then she ran to the door and peeped through the hole. (11) Then, when she looked, a lamb appeared. Then the sow opened the locked door and asked: "Who are you? What a gentle wind drove you to my poor hut?" (12) "I am the lamb of the old goat who lived in your neighbour valley. My mother let me send you some salted fish as a gift." (13) The sow accepted the fish from the lamb. (14) The fish was very large and the scale on his body was sparkling like fire. (15) Owing to the fat of the fish, its oil was dropping. (16) Being very happy the sow gave wheezy sound. (17) For a long time the sow did not eat fish meat. (18) Giving wheezy sound and looking at the lamb the sow said: "Please send my good wish to your mother." (19) "OK," (the lamb) gave an answer and bidding (bleating) farewell went back home. (20) Then, the sow came to tripod, fed her little sons with the hot porridge and herself sat down to eat the fish. (21) She ate the fish completely (lit. from head to tail). She ate the whole fish until the bare bone was left. (22) The sow thought: "If someday I can (again) eat such a fish, how good it is (lit. it would not be bad)." (23) Then she brought her little sons to outside and let them lie down at the warm mire, she herself lay down to let her old bone get sun. (24) Then, before long, while the sow lay (on earth) together with her sons, lastly she was thirsty (lit. her want to drink water came). (25) Then she stood up 
and said to her sons: "You continue to lie down at the mire, I go to drink water." (26) Thus, (the sow) went to water along a narrow road. (27) So, arriving at the water she began to drink the cool water with enjoyment. (28) While she was drinking water, suddenly a wolf appeared. Nobody knows from where he came. (29) As soon as that wolf saw the sow, he jumped up on the sow's body and stuck his sharp teeth in the neck of the sow. (30) "Now I will eat you, when I saw you, my mouth flowed slaver. Only you did not fall to my hand," he said. (31) The sow thought: "Really it became bad (lit. difficult). Although wolf is very fierce in the forest, but no one is more stupid than him. Let me try to cheat him." (32) Then the sow begged with soft words: "Please, don't eat me! (33) My flesh of armpit is hard as stone, my head is like a stump, my thigh like wood, don't eat me, please, cherish your sharp teeth. Instead of this, I will entertain you well. I will give you my three children (to eat). My children are not old. Their meat is as fat as shank. Moreover (their meat) is as red as apple in the garden." (34) The wolf said: "Your saying is correct. Your flesh of armpit is like stone, your head is like stump, your thigh is like wood. For me it is better to eat your children's soft, delicious meat than to harm my sharp teeth by your old bone." (35) After hearing the grey-mane wolf's words the sow was very happy. (36) She said with soft, good words: "Oo, wise grey-mane wolf, today after it becomes dark, please, come to the valley where we live. Then, you call firstly my oldest son, then my second son, lastly my youngest son, they will come out. Thus you can eat them." (37) After hearing those words the wolf's eyes sparkled. Gritting his teeth he asked the sow: "What are your sons' names?" (38) Then the sow said: "My oldest son's name is Šay, the second one's is Jiliz, the youngest's is Bïžix." (39) "OK, I will let you go home. In the evening I will go to your children," (said the wolf). (40) "At any rate, please, come, don't cheat your old friend! I will feed my children well and let them become more fat." Saying that the sow ran to her house. (41) "I will go, why I do not go!" said the wolf and entered into the thick forest. (42) After the wolf entered the forest and lay down, he thought by himself: "Oy, how stupid this old sow is! She gave me all her children, moreover still not being at ease: she fears that I would not come." (43) The sow ran to her house, took up her little sons from the mire and nursed them, then entered the house, let the children lie on the dried hay, firmly locked the door, then lay down at the side of her children. (44) In the late evening the wolf ran out from the thick forest (45) and howled: "Ay, old sow, tell your (oldest) son Šay: let him come to me. We play the hide-and-seek!" (46) The sow lying in the house gave the answer: "Oo, grey wolf, the time is too late, isn't it? I've already let my children lie down on the soft bed and sleep." (47) Being angry the wolf again howled: "Ay, old sow, tell your (second) son Jiliz, let him come to the valley and play the hide-and-seek with me!" (48) "My son Jiliz is also asleep like my other sons on the straw bed," answered the sow to the wolf. (49) Being very angry the wolf jumped up repeatedly. "Ay, you old sow, tell your youngest son Bižix, let him come out to play 'little boy play' with me," howled (the wolf) with a valley-shaking strong voice. (50) "The door of my hut was firmly closed. So, no ferocious wolf can enter. Go away to the forest, you grey dog! Next time be wiser!" said the sow. (51) "Stop! You cunning sow, if you some- 
day fall to my mouth," howled the wolf. (52) Howling and gritting the teeth, the wolf along a forest road went far away.

\section{Commentaries}

D2 uruu: < uruy 'daughter' + -ï (3rd per. poss.) 'his daughter'.

D2 jorïptur: < jorï- 'to go' + -p converb + aux. verb 'tur' (stand) indicating past narrative tense.

D3 bodaaštan: < boda- 'think' -yaš (past converb) + -tan (ablative).

D3 jadaaš: $<$ jada 'cannot' + -yaš (past converb).

D4 sayiiš bit-/büt-: 'an idea comes to being'.

D5 qïyïrtïbaap: < qïyïrtip + alïp.

D5 inya: < ol 'he, it' + -ya (dative) 'to him'.

D5 ööy: < öy 'home' + -in (2nd per. poss.) 'your home'.

D5 uruun: < uruy 'daughter' + -uy (2nd per. poss.) 'your daughter'.

D6 dïnnaaš: < dïnna- 'to hear' + -yaš (past converb).

D6 geeptur: < gelip + tur.

D7 gelgäš: < gel- 'to come' + -gäš (past converb).

D7 dužaan: < dužaa- 'to give order' + -yan (past participle).

D7 jarliïn: < jarlïq 'order' + -i (3rd per. poss.) + -n (accusative) $>$ jarlïqïn $>$ jarlïyïn $>$ jarliïn.

D9 oon soonda: 'after that, then' $<$ oon (genitive of pronoun 'ol' he, it), soonda $<$ son 'end' $+\ddot{i}-n+-d a$.

D9 eškeš: < eš- 'to twist' + -keš/-käš (past converb).

D9 qaayaštan: < qay- 'to put' + -yaš (past converb) + -tan (ablative).

D10 ežerin: < eš- + -er (aorist) + -i (3rd per. poss.) + -n (accusative).

D10 ežip qaydïm: 'I have twisted (the rope)'. qay- 'to put' was used as aux. verb indicating a finished action.

D10 jiïp: < jïy- 'to collect' + -ïp (-p converb).

D13 qanjalï: < qanjal- (pronominal verb 'what to do') + -ïr (present-future participle).

D13 dïppayïn: < tïp- 'to find' + -payïn (negative converb).

D14 adinniin: < adiynïn 'of bear'. In TC $-\gamma$ at the end of a word becomes $-\eta$ when after it genitive suffix beginning with -nin/-nïn follows.

D16 ekkel: 'bring it here'. < alip 'taking' + kel 'come'.

D17 oruu: < oruq 'road' + -ï (3rd per. poss.).

D17 qaaptur: here 'qaap' should be a converb form of 'qayïp' of verb 'qay-' (to put) plus aux. 'tur', not from the converb 'qalïp' of verb 'qal-' (to stay).

D18 geliger: 'please you come'. In TR the corresponding form is 'geliner'. In TC the form is the same as in Sibirian Altaic (Oyrot) language.

D19 qanjap: $<-$ p converb form of verb 'qanjaar' (what to do).

D19 geeptur: < geliptur 'he came'.

D20 geli(i)jïdarda: 'when he was coming' $<$ geli + jït + -ar + -da. 
D21 ööngä: 'to his house' < öy 'house' + -i (3rd per. poss.) + -n (epenthetic) + -gä (dative).

D28 yeri: 'male', when 'e' appears at the initial position of a word, there is a strong prothetic ' $y$ '.

D28 deešten: 'saying' < de- 'speak' + -geš (converb) + -ten (ablative).

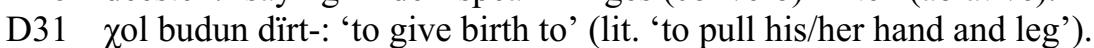

D32 törürbä: 'does he/she give birth to ...?' In my original text it is written as 'törülbä', it should be a mistake.

D33 jünü aytïydïrsiler: 'what are you saying?' 'aytïydïr' may be a special, emphatic form of 'aytadïr' (he says) < v. 'ayt-' (to say) + -a (-a converb) + -dïr (aux. v.).

D35 dažïrar: 'insult' < M. 'tašaaral' (?).

D35 gedi(li)ptur: My informant translated this sentence as 'she was freed from the insult of the khan.' Cf. TRS p. 219 (obsolete word) 'kediler' (being freed from...). Etymologically it comes from 'ket-' (to go away) in other Turkic languages.

E1 men: 'and', 'with' < K. 'men' id.

E1 qayay: 'sow'. In TR it is 'qawan'.

E3 adaan: 'named' < ada- 'to name' + -yan (past indefinite).

E4 yaš: 'wood', this word is always pronounced as 'yãš' (nasalised).

E4 doorsinda: 'at the corner of', the normal form should be 'doorsusïnda/doorzusïnda'.

E4 kükpäk: 'hut' < K. 'küpänä' (haystack) (?) (with metathesis p/k).

E5 mindin: 'porridge' (?). I can't identify this word. Maybe it is related to 'mün' (soup) in TR and Sarigh Uig.

E7 anjal-: 'to do like this' = TR 'ïnčal-' id.

E7 ooldarïnen qadï: 'together with her children'. My informant first used '...men qadï' (cf. E24, E42), but later changed to '....nen qadï'. In E39 once again 'gejä bolurnan' (not 'bolurmen') was used. Cf. D4 'sösternen' (with ... words). The -men form should be influenced by Kazakh language.

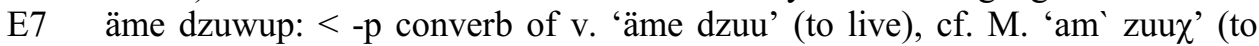
live) (MRS, p. 36).

E7 jörüy = jorïy (-a/-y converb of v. 'jorï-').

E8 qudu: 'towards'. The meaning is some different from TR and OT (downward).

E9 däl: $<$ K. däl (just).

E9 ges: $<\mathrm{K}$. 'kes' (time).

E10 suraaštan: 'asking'. My informant said it is better to say 'surabïtqaš' ( $<$ surap + it + qaš).

E11 köstür: a habitual form derived from verb 'kör-' (to see) with the meaning 'to appear'.

E11 dekpilä-: < tepkile- 'to kick', 'to seize' (with repetitive suffix '-kile' and p/k metatheses).

E11 ejiin: < ežik/ejik 'door' + -i (3rd per. poss.) + -n (accusative).

E11 ažïdïwïtqaš: < ažïdïp (< ažit 'to open') + ït (to send), + qaš (converb).

E11 zalyïn: 'gentle breeze' = TR 'salyïn' . 


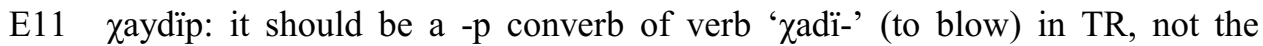
Kazakh -p converb of verb 'aydap' (driving).

E12 dustaan: 'salted (fish)' < dusta- + -yan (past participle).

E13 aldir: 'she accepted', it should be an oral (shortened) form of 'aladir' (present reported tense).

E14 ušqaš: 'like', it comes from 'uqšaš' through metathesis, cf. Uig. 'oxšaš', K. 'uqsas' id.

E15 $\chi$ aaptur: my informant translated this word as 'flowed'. Compared with E30 'qayadïr' (flowed), the stem should be 'qay-/ $\chi$ ay-'. But in TRS this verb means only 'strike, hit', having no meaning 'to flow'. Maybe it is a special idiomatic use of the verb 'qay-' in TC.

E15 bir eleennen beri: 'since a longer time'. Here an unnormal ablative suffix -nen is used instead of '-den'.

E19 da/dä: here it should be a particle, borrowed from K. (expressing that two actions happen one after another).

E19 mäläbitkaš/mäläwitkäš: < mälä- 'bleat' + -p + -it + -käš.

E19 mendiläškäšs: 'extending greetings to each other' $<$ mendi 'healthy' $(<\mathrm{M}$.

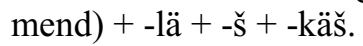

E21 söök-tayaan: < söök-tayaq/dayaq 'bone' $+-i \ddot{i}+-n$.

E23 jašti: 'outside' $=$ TR 'daštî' id.

E24 üremäš: < ür 'long time' + emääš 'little' (cf. TR 'eweeš').

E24 adaanda: 'at the end' < adaq 'end' $+-i+-n+-d a$.

E26 joy bardi: 'went away' = jorïy bardi.

E27 sunnï: 'water' (accusative). When after a word ending with $-\gamma$ a suffix beginning with $-n$ is added, the $-\gamma$ changes to $-\eta$ in TC.

E28 qayniïn gelgen: 'from where he came'. The normal form should be 'qayiiin gelgen'.

E29 gör säli: 'as soon as he saw'. The normal form should be 'köre sala' (-a converb + aux. verb sal- 'to put'.

E29 jitkäzinä: 'to its neck', here the dative 'nä' is the Kazakh's influence.

E30 jaraa(m) qayadir: '(my) slaver is drooling'. From this phrase we know that the verb 'qay-' has the meaning of 'to flow', cf. E15 ' $\chi$ aaptur'.

E31 bodaaš: 'thinking' < boda- + yaš.

E31 unun: according to the context, it should be the ablative case of the 3rd personal pronoun 'ol' (he, it) $-<$ on-dan. Here maybe it is a dialect form in TC.

E33 bïqt(im): 'the flesh under armpit' (R. p. 1307).

E33 moon ezesinä: 'making compensation for this', 'instead of it'. 'moon' (genitive of 'bo' - this), eze $<$ K. ese 'contribution' + -si $+-n+$ ä.

E34 daman: 'rear foot' $=$ dawan of TR.

E36 däriy: 'then' < M. 'daraa' (MRS, p. 145).

E37 qaraa: 'his eye' < qaraq 'eye' + -ï.

E37 qayaynan: 'from the sow'. In TR only -dan/-tan two sets of variants are used. Accordingly here should be '-dan'.

E38 uluu: 'the biggest' $<$ uluy + -i. 
E40 semirinkirä-: 'to become more fat' $<$ semeri- + -nkirä (intensive suffix adding to verb stem).

E42 tenee[n]: 'his foolishness' $<$ tenek +- i.

E42 qaybayïn: it should be negative form of verb 'qay-/ $\chi$ ay-' (to close) with the transferred meaning 'not set one's mind at rest'.

E43 giirgeš: 'letting enter' < giir 'to let enter' + -geš.

E43 döžäängä: 'to his bed' < döžäk $+-i+-n+$-gä.

E43 ejiin: 'his door' (accusative) $<$ ejik $+-i+-n$.

E43 qïdiïnya: 'to his side' < qïdì 'side' $+-\mathrm{i}+-n+-$-ya.

E43 bilen: 'with' instead of TR 'bile'.

E45 soyurdegä: 'hide-and-seek' $<\mathrm{K}$. 'soqïrteke' (blind goat).

E47 ayt-aan: < ayt- 'say' + -aan (affirmative particle).

E47 jaštïp oynãr: = soyurdegä.

E50 ne dä: 'whatever kind of'. But my informant translated as 'hateful'.

E50 töbet: 'male dog' $<\mathrm{K}$.

E51 bäl(em): '(my) terrible fellow' $<$ K. 'päle' id.

\section{List of Grammatical Suffixes}

\begin{tabular}{|c|c|c|}
\hline D1 & -ptur/-ptür/-ptïr/-ptir & past narrative \\
\hline D1 & -da/-de/-ta/-te/-nda/-nde & locative \\
\hline D2 & -ar/-er/-ïr/-ir/-ur/-ür & aorist \\
\hline \multirow[t]{2}{*}{ D2 } & $-\chi a /-g a ̈ /-q a /-k e$ & \\
\hline & -(i)na/-(i)ne/-(zi)na/-(zi)ne & dative \\
\hline D3 & -men & 1st per. pronominal s. \\
\hline D3 & -qan/-ken/-yan/-gen & past participle \\
\hline \multirow{3}{*}{ D5 } & -nï/-ni/-nu/-nü & \\
\hline & -dï/-di/-du/-dü & accusative \\
\hline & -tï/-ti/-tu/-ẗ̈ & \\
\hline D5 & -qaš/-keš/-yaš/-geš(-š) & past converb \\
\hline D5 & -dan/-den/-tan/-ten/-nan/-nen & ablative \\
\hline D5 & -dayï/-dägi & adjective (with locative meaning) \\
\hline D5 & -p/-ïp/-ip & connective converb \\
\hline \multirow{2}{*}{ D5 } & -tïr/-tir/-dïr/-dir, -t, & \\
\hline & -qür/-kir/-qüz/-yïz & causative \\
\hline D5 & -za/-ze/-sa/-sä & conditional \\
\hline D5 & -ïm/-im/-m & 1 st per. poss. \\
\hline D5 & -ïy/-in & 2nd per. poss. \\
\hline D8 & $-\mathrm{i} /-\mathrm{i} /-\mathrm{zi} /-\mathrm{zi}$ & 3rd per. poss. \\
\hline D8 & -ba/-bä/-pa/-pä/-ma/-mä & negative \\
\hline D10 & -sun/-sün/-sïn/-sin & 3rd per. imperative \\
\hline D11 & $-n$ & epenthetic suffix after 3 rd per. pos \\
\hline
\end{tabular}



D13 -payïn/-peyin -bayïn/-beyin -mayïn/-meyin
D14 -nїy/-nij/-nuy/-nüy/ -dïn/-din/-dun/-dün -tïy/-tip/-tuy/-tün
D18 -(i)yar/-(i)gär/-(i)ger
D18 -dï/-tï/-du/-tu/-dü/-tü
D19 -ayïn/-eyin
D20 -a/-e/-y + jït-
D23 -qïja/-kijä/-rïja/-gijä
D23 -baan/-bään/-paan/-pään -maan/-mään
D25 -bas/-bes/-pas/-pes
E5 -lar/-ler/-dar/-der -tar/-ter/-nar/-ner
E11 -sen
E20 -a/-y + -dïr/-dir/-dur/-dür
E22 ezä
E25 -ayïn/-eyin
E28 -bay/-bey/-pay/-pey/-may/-mey
E30 -jïq/-jik/-juq/-jük
E31 -sa da/-sä dä
E36 -men
E45 -ray/-gey/-qay/-key
E46 -ba/-bä/-pa/-pä

\author{
negative pres. converb \\ genitive \\ 2nd pl. poss. (also used in verb denoting \\ politeness) (instead of -nar... of TR) \\ past categorical \\ 1st sing. imperative \\ -a converb + aux. jït- (to lie) denoting \\ an action in progress \\ limiting converb \\ negative form of past participle \\ negative aorist \\ plural \\ 2nd per. pronominal s. \\ present reported tense (out of sight) \\ conditional particle \\ 1st per. sing. imperative \\ negative converb \\ past rhetorical \\ concessive construction \\ instrumental \\ optative \\ questional particle
}

\section{Glossary}

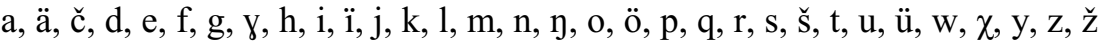
Because of technical reasons, I used letter ' $j$ ' for [ $\left.\mathrm{d}_{3}\right]$

$\begin{array}{llll}\text { ada } & \text { D8 'father' } & \text { alma } & \text { E33 'apple' } \\ \text { ada- } & \text { E3 'to name' } & \text { amdannï } & \text { E34 'delicious' } \\ \text { adaq } & \text { E24 'end' } & \text { amdï } & \text { E30 'now' } \\ & \text { ey adaanda 'at the end' } & \text { anay = änäy } & \text { E11 'lamb' } \\ \text { adïy } & \text { D14 'bear' } & \text { anjal- } & \text { E7 'to do like this' } \\ \text { adïr } & \text { D30 'just wait a moment' } & \text { ay } & \text { E31 'animal' } \\ \text { adïrïl- } & \text { D21 'to lose' } & \text { aryamjï } & \text { D5 'rope' } \\ \text { al- } & \text { D3 'to take' } & \text { arï } & \text { E3 'forest' } \\ \text { alda- } & \text { E31 'to cheat' } & \text { ašqïjaq } & \text { D1 'old man' }\end{array}$




\begin{tabular}{|c|c|c|c|}
\hline at & E37 'name' & bögün & D30 'today' \\
\hline ayt- & D5 'to say, to tell' & böyde & D26 'all' \\
\hline aži- & D28 'to turn sour' & börü & E1 'wolf' \\
\hline ažïn- & E47 'to be angry' & burun & D1 'before' \\
\hline \multirow[t]{2}{*}{ ažït- } & E11 'to open' & but & D3 'fut' \\
\hline & & büdün & E21 'whole' \\
\hline aas & D17 'mouth' & $\mathrm{da} / \mathrm{dä}$ & D33 conjunctive particle \\
\hline aaldaš & E12 'neighbour' & day & D13 'mountain' \\
\hline \multirow{2}{*}{ aamay } & F31 'stunid' & dayïn & D9 ‘again’ \\
\hline & E51 stupid & dalašpayïn & D15 'not hurrying' \\
\hline & & daman & E34 'leg' \\
\hline \multirow{2}{*}{ änäy = anay } & E7 'to live' & daš & D9 'stone' \\
\hline & E11 & dažïrar & $\begin{array}{l}\text { D35 'insult' } \\
<\text { M. 'tašaaral' (?) }\end{array}$ \\
\hline $\mathrm{ba} / \mathrm{bä}$ & D32 question particle & däl & E9 'just' \\
\hline bayay & E22 'bad' & & $<\mathrm{K}$. 'däl' id. \\
\hline balyaš & E23 'mud' & däriy & E36 'then' \\
\hline balïq & E12 'fish' & & < M. 'daraa' id. \\
\hline baqiila- & E10 'to look' & de- & D3 'to say’ \\
\hline baqša & E33 'garden' & dekpilä- & E11 'to shut tight' \\
\hline bar & $\mathrm{D} 23, \mathrm{E} 2$ 'there is, to exist' & & $<$ depkilä- 'to kick \\
\hline bar- & D10 'to go' & & repeatedly’ \\
\hline baš & D5 'head' & dez- & D21 'to escape' \\
\hline bašqa & E48 'other' & diš & E29 'tooth' \\
\hline bašta- & E27 'to begin' & dïdïq & E10 'hole' \\
\hline bat- & E34 'to sink' & dïna- & D6 'to hear' \\
\hline baza & E33 'again' & dïnsï $\chi$ & E49 'strong' \\
\hline belek & E12 'gift' & dïp-/tïp- & D3 'to seek' \\
\hline belen & D8 ‘easy’ & dïrt- & D31 'to pull' \\
\hline beeri & E17 'since' & & D33 (here it means \\
\hline bičii & D30 'little' & & 'cherish') \\
\hline bil- & D25, E28 'to know' & dolu & D22 'many' \\
\hline bir & D1 'one' & doqtaa- & D30, E51 'to stop' \\
\hline bis & D36 'we' & dorzuq & E33 'shank' \\
\hline \multirow[t]{2}{*}{ bit-/büt- } & D4 'to achieve, to bring & doorsu & E4 'corner' \\
\hline & about' & dögä- & E23 'to get warm, to sun' \\
\hline bïqt & E33 'flesh of armpit' & döžäk & E43 'bed' \\
\hline bo & D23 'this' & dur-/tur- & D26, E4 'to stand' \\
\hline boda- & D3, E22 'to think' & dura & E24 'desire' \\
\hline bodu & D9 'himself' & dusta- & E12 'to salt' \\
\hline bol- & $\begin{array}{l}\text { D18, E1 'to become, } \\
\text { there is' }\end{array}$ & dužaa- & $\begin{array}{l}\text { D7 'to hand over, to } \\
\text { deliver' }\end{array}$ \\
\hline boljaq & E24 'time' & düš- & E30 'to fall' \\
\hline
\end{tabular}




\begin{tabular}{|c|c|c|c|}
\hline \multirow[t]{2}{*}{ eder- } & E23 'to follow' & ïraq & E52 ‘far’ \\
\hline & $\begin{array}{l}\text { edert- E23 'to let follow, } \\
\text { to lead' }\end{array}$ & iiittaa- & E16 'to give a sound' \\
\hline \multirow[t]{2}{*}{ egin } & D17 'shoulder' & jada- & D3 'cannot' \\
\hline & ekti 'his shoulder' & jalïn- & E32 'to beg' \\
\hline ejik & E10 'door' & jan- & D28 'to go back' \\
\hline ekkel- & $\begin{array}{l}\text { D16 'to take, to bring' } \\
<\text { alïp kel- 'taking come' }\end{array}$ & janï- & $\begin{array}{l}\text { E37 'to make sharp, } \\
\text { to grind' }\end{array}$ \\
\hline eleen & E17 'a longer time’ & jayjïryalandïr & E49 'reverberating' \\
\hline emäs & E33 'mot' & jayyïs & E26 'one, single' \\
\hline emääš & E24 'little' & jaraa & E30 'saliva' \\
\hline ep & D3 'means, method' & jarïq & E12 ‘valley’ \\
\hline eptix & E32 'suitable' & jarlïq & D7 'order' \\
\hline \multirow[t]{2}{*}{ ergin } & E2 modal particle & jaš & D23 'age’ \\
\hline & (expressing narration) & jaš $\sim$ jãš & E33 'wood' \\
\hline ertä & E1 'early' & jaštï & D29, E14 'outside' \\
\hline erten & D28 'tomorrow' & jaštï- & E47 'to hide' \\
\hline eš- & D5 'to twist' & jaštïy & D2 'young' \\
\hline e’t & E17 'meat' & ječen & D4 'cunning (words), \\
\hline ezä & E22 conditional particle & & artful' \\
\hline \multirow[t]{2}{*}{ eze } & E33 'share, contribution' & jedir & E21 'until' \\
\hline & $<$ hässä (< p. -a.) id. & jel & E35 'mane' \\
\hline gejä & E6 'evening' & jemnendir- & E20 'to feed' \\
\hline gejää & D13, E31 'difficult' & jer & D13 'place’ \\
\hline get-/ket- & D35 'to go away' & jeerlä & E30 'only' \\
\hline giir- & E43 'to let enter' & jibe & D8 'thing' \\
\hline güstür & E11 'to appear' & jidiy & E29 'sharp' \\
\hline \multirow[t]{2}{*}{ gükpäk } & E4 'hut' & jigä & E34 'straight' \\
\hline & & jilmilen- & E27 'to be greedy' \\
\hline inek & D28 'cow' & jit- & E50 'to get away' \\
\hline iš- & E24 'to drink' & jitkä & E29 'neck' \\
\hline išt(i) & E31 'inside' & jiwä $=$ jibe/jibä & E9 \\
\hline iye & E8, 12 'mother' & jïy- & D10 'to pick up, to \\
\hline iyi & D26 'two' & & collect' \\
\hline \multirow[t]{3}{*}{ iyik } & E22 particle express- & jïlïy & E3 'warm' \\
\hline & ing narrative in past & jïmjaq & E34 'soft' \\
\hline & $(<$ er-'to be') & jït- & D20, E6 'to lie' \\
\hline iyinči & E50 'second' & jobalanjoq & E7 'worriless' \\
\hline iziy & E20 'hot' & joqtuy & D1 'poor' \\
\hline \multirow[t]{2}{*}{ ižään } & D14 'den’ & jorï- & D1 'to go' \\
\hline & & jörü- = jorï- & E7 \\
\hline ïndïy & D22 'of that kind' & jü & D32, E42 'what' \\
\hline ïnya & D5 'to him' & & jü deen $(<$ degen $)$ \\
\hline ïnjan & E36 'at that time' & & 'how, what' \\
\hline
\end{tabular}




\begin{tabular}{|c|c|c|c|}
\hline jügür- & E10 'to run' & orčalay & $\begin{array}{l}\text { D22 'world' } \\
<\text { M orčlong id. }\end{array}$ \\
\hline kedi(l)-/gedi(1)- & D35 'to be freed' & orta & E36 'middle' \\
\hline kel-/gel- & D6 'to come' & ortta & $\mathrm{D} 25$ 'then, at that time' \\
\hline kenerten & E28 'suddenly' & oruq & D20, E26 'road' \\
\hline kenjä & E49 'youngest' & osqun- & D6 'to lose' \\
\hline keräk & D13 'matter' & ot & D26, E14 'fire' \\
\hline kerbä & D15 'if’ & oyna- & E45 'to play’ \\
\hline kes/ges & E9 'time’ & ool & E5 ‘son’ \\
\hline kiji & D16 'human being' & oon & D2 genitive of 'ol' \\
\hline kök & E35 'blue, grey’ & & ooy soonda D9 'later, \\
\hline kör- & D11 'to see' & & after that' \\
\hline kükpä & E11 'hut’ & & \\
\hline kül & D5 ‘ash’ & öčük & E19 'answer' \\
\hline kün & $\begin{array}{l}\text { D4, E5, E23 ‘day, } \\
\text { sun’ }\end{array}$ & $\begin{array}{l}\text { öy } \\
\text { öl- }\end{array}$ & $\begin{array}{l}\text { D5, E19 'house, home' } \\
\text { D16 'to die' }\end{array}$ \\
\hline mälä- & E19 'to baa' & ölü & E48 ‘dead’ \\
\hline megelä- & E40 'to cheat' & örttet- & D9 ‘tu burn’ \\
\hline men & $\begin{array}{l}\text { D5 'I' } \\
\text { mengä (dative) }\end{array}$ & $\begin{array}{l}\text { örü- } \\
\text { öt- }\end{array}$ & $\begin{array}{l}\text { E16 'to be happy' } \\
\text { E46 'to pass' }\end{array}$ \\
\hline men & E1 'and' & öy & E46 'time' \\
\hline mendi de- & $\begin{array}{l}\text { E18 'send one's } \\
\text { regard to' }\end{array}$ & qadï & E7 'together' \\
\hline $\begin{array}{l}\text { mendilä- } \\
\text { meen }\end{array}$ & $\begin{array}{l}\text { E19 idem } \\
\text { E11 'my' }\end{array}$ & & $\begin{array}{l}\text { (with instrumental case } \\
\text { '-men') }\end{array}$ \\
\hline mindin & E5 'porridge' (?) & qay- & D9 'to put' \\
\hline mijïy & E3 'solid, sturdy' & qay-/xay- & E42 'to close' \\
\hline monï & $\begin{array}{l}\text { D23, E31 'this' } \\
\text { (accusative) }\end{array}$ & $\begin{array}{l}\text { qayay } \\
\text { qal- }\end{array}$ & $\begin{array}{l}\text { E1 'sow' } \\
\text { D17 'to stay' }\end{array}$ \\
\hline mundïy & D23 'of this kind' & & qaaptur < qalïptur \\
\hline munyaštan- & $\begin{array}{l}\text { D33 'to be in } \\
\text { awkward situation' }\end{array}$ & $\begin{array}{l}\text { qandïy } \\
\text { qanjal- }\end{array}$ & $\begin{array}{l}\text { E11 'what kind of' } \\
\text { D13 'how to do' }\end{array}$ \\
\hline murunay & E36 'firstly' & $\begin{array}{l}\text { qanjap } \\
\text { qarayyï }\end{array}$ & $\begin{array}{l}\text { D19 'how (to do)' } \\
\text { E36 'dark' }\end{array}$ \\
\hline ne dä & E50 'whatever' & qaraq & E37 ‘eye’ \\
\hline oyul & E2 son & qaybir & E5 'some' \\
\hline ojuq & $\begin{array}{l}\text { oylu 'his son' } \\
\text { E20 'tripod' }\end{array}$ & qayniïn & $\begin{array}{l}\text { E28 (= qayiiin) 'from } \\
\text { where' }\end{array}$ \\
\hline ol & D8 'that, it' & qažanda & E50 ‘whenever' \\
\hline olur- & D15 'to sit' & qïdïy & D26, E43 'edge, side' \\
\hline onï & D3 accusative of 'ol' & qïyïr- & E36 'to call' \\
\hline oray & E44 'very late’ & qiil- & D25 'to do' \\
\hline oraa- & $\begin{array}{l}\text { D4, E6 'to wrap, to } \\
\text { wind' }\end{array}$ & $\begin{array}{l}\text { qïlïn } \\
\text { qïlanyaynï- }\end{array}$ & $\begin{array}{l}\text { E41 'thick' } \\
\text { E14 'glisten' }\end{array}$ \\
\hline
\end{tabular}




\begin{tabular}{|c|c|c|c|}
\hline qïm & E10 'who' & suy & E24 'water' \\
\hline \multirow[t]{2}{*}{ qïr } & D9 1) ‘edge, point' & sura- & E10 'to ask' \\
\hline & $\begin{array}{l}\text { 2) positional noun } \\
\text { (on...) }\end{array}$ & süt & D28, E43 'milk' \\
\hline qïryan & E1 'old' & šay & D1 'time' \\
\hline qïrïin & E1 'very' & šimää & D18 'information' \\
\hline qïrtïš & E14 'scale (of fish)' & šïn & E33 'true' \\
\hline qïšï̌r & E49 'to call' & & \\
\hline qïy de- & D29 'to shout' & taraq & D28 'yoghurt' \\
\hline \multirow[t]{3}{*}{ qï(y)ÿ̈r- } & D5 'to call' & tenek & E42 'stupid' \\
\hline & qï(y)yïrt- 'to let someone & tod- & E5 'to eat one's fill' \\
\hline & to call' & töbet & E50 'male dog (or wolf)' \\
\hline \multirow[t]{2}{*}{ qïzïl } & E33 'red' & törü- & E32 'to give birth' \\
\hline & qïp-qïzïl 'very red’ & tözin & D7 'all, complete' \\
\hline \multirow[t]{2}{*}{ qort- } & D6 'to fear' (the stem is & töžäk & E33 'stump' \\
\hline & qortpa 'don't fear') & udaa & E50 ‘time’ (classifier) \\
\hline qudu & E8 'toward' & udu- & E46 'to sleep' \\
\hline quduruq & E21 'tail' & uyan & D6 'wisdom' \\
\hline \multirow[t]{2}{*}{ qujaq } & D9 'armful' & uyannïy & E36 'wise' \\
\hline & & ulu- & E51 'to howl' \\
\hline sabïn & E6 'hay' & uluy & E14 'big' \\
\hline sayï̌s & D4 'thought' & unuun & E11 'then' \\
\hline \multirow[t]{3}{*}{ sal- } & D9 'to put' (also used as & uruy & D2 'girl, daughter' \\
\hline & aux. verb expressing 'as & ušqaš & E14 'like' \\
\hline & soon as') & uyyu & E48 'sleep' \\
\hline sana- & D14 'to count' & užun & E40 'for, in order to' \\
\hline semiz & E15 'fat' & & \\
\hline \multirow[t]{2}{*}{$\operatorname{sen}$} & D5, E25 ‘you’ & üčǖči & E3 'third' \\
\hline & seen D5 'your' & ün- & D31, E23 'to go out' \\
\hline serin & E27 'cool' & ür & E24 'long (time)' \\
\hline sigen & D9 'grass' & üs & E15 'fat, grease' \\
\hline \multirow[t]{2}{*}{ siler } & D24 'you' (pl. polite & üš & D20 'three' \\
\hline & form) & üškü & E11 'goat' \\
\hline simirinkirä- & E41 'to make more fat' & üt & D18 'hole' \\
\hline \multirow[t]{2}{*}{ soyurdegä } & E45 'hide-and-seek' & & \\
\hline & (lit. 'blind goat') & 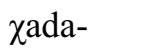 & D17 'to insert' \\
\hline \multirow[t]{3}{*}{ son } & D9 'end' & xay-/qay- & E15 'to flow' \\
\hline & soonda D26 'then, at the & xay- & E9 'to close' \\
\hline & end' $<$ soy $+-\ddot{i}+-n+-d a$ & xaydïn- & E5 'to be closed' \\
\hline sös & D4 'word' & zalii- & E29 'to jump' \\
\hline söök & E23 'bone' & zan & D3 'khan' \\
\hline sööktäyaq & E21 'bone' & 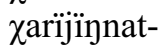 & E52 'to grit one's teeth' \\
\hline
\end{tabular}




\begin{tabular}{|c|c|c|c|}
\hline xariii ber- & E46 'to answer' & 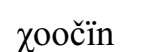 & E40 'old' \\
\hline ұaydï- & E11 'to blow' (cf. $\chi$ adï- & yaš $\sim$ yãš & E4 'forest' \\
\hline ұayïndïr- & E5 'to boil' & & E19 'good' \\
\hline & D31 'hand' & yekile- & E33 'to do well' \\
\hline ұonača & E33 'guest' & & \\
\hline ұortilda- & E16 'to wheeze' & zalyïn & E11 '(gentle) wind' \\
\hline
\end{tabular}

\section{Abbreviations}

K.: Kazakh

M.: Mongolian

MRS: Mongol'sko-Russkiy Slovar'. 1957. Ed.: A. Luvsandendev.

OT: Old Turkic

R: $\quad$ Radloff, V. V.: Opït Slovar'Tyurkskikh Narečiy. 1893.

TC: Tuvinian of China

TR: Tuvinian of Russia

TRS: Tuvinsko-Russkiy Slovar'. 1955. Ed.: A. A. Pal'mbakh (with appendix 'Outline of Tuvinian Grammar' by Š. Ch. Sat)

( ): The letter in parentheses is added by the author.

[ ]: The letter in square brackets should be deleted. 